\title{
The social responsibility of corporation and its impact on the reformation of corporate governance structure: a discussion from the perspective of law
}

\author{
Li Beiling $^{1}$, Wang Jing ${ }^{2}$ \\ ${ }^{1}$ Northeastern University at Qinhuangdao, 066000 \\ ${ }^{2}$ Hebei Vocational College for Correctional Police, 056004
}

\begin{abstract}
Keywords: Company; Corporation social responsibility; Corporate governance
\end{abstract}
\begin{abstract}
Corporation social responsibility is no longer only a concept existing in theoretical research field, but has extended its scope into solving practical problems. The emergence and development of theories concerning corporation social responsibility has exerted a vast and even subversive influence on the modification of traditional company law and the reshaping of corporate governance structure. From the perspective of law, this paper gives a brief introduction to the world's major countries' reaction towards the reform of corporate governance models under the influence of corporation social responsibility. In view of the status quo of the operation of corporate governance and the existing laws and regulations in China, this paper aims to puts forward a feasible corporate governance system and development path specific to China's national conditions from three aspects: "expanding its explanation of corporate purpose and perfecting the duty rules of the board of directors", "setting up social responsibility committee under the board of directors" and "strengthening the protection of workers' interests", which altogether will make a great contribution to the advancement of corporate governance in China.
\end{abstract}

\section{The Definition of Corporation Social Responsibility}

Corporation social responsibility is a controversial topic from the time of its birth. Objections are that once the company admits that it has social responsibility, all kinds of groups will propose requirements to the company. The results will shake free capitalist private property ownership, and bring about market mechanism disorder. American economist Milton Friedman argues that company has a sole kind of social responsibility, which is to make maximum the profits for shareholders by using resources in activities. Scholars with positive opinion argue that company holds the duty of society, that is to request company's decision makers consider the benefit of other stakeholders in addition to consider shareholder interests when making business decisions. This can resolve the contradictions between profit and public policy.

In mid and late 20th century, the issue of corporation social responsibility attracted Chinese scholars' study interest and close attention, and distinctive concept expressions are formed. Among them, professor Lu Daifu thinks that corporation social responsibility is the enterprise's seeking and satisfying of social benefits, which is to maintain and improve social interests. This obligation and maximizing shareholders' interests both constitute corporation social responsibility and economic responsibility. 1 Taiwan scholar professor Liu Lianyu argues that for-profit enterprise decision-making authority should give up profit-making intention and serve for the majority's expectations after confirming that a certain matter conforms to most people's expectations. 2

From the above Chinese and western scholars' definition of corporation social responsibility, although the expressions are different, all contain the common understanding of the concept, namely due to the double attributes of corporation personality, on the one hand, the company should reflect its economic efficiency and make profit for shareholders; on the other hand, also want to reflect its sociality, that is to take social goal as company's responsibility, which must take into account the interests of other stakeholders. 


\section{The Influence of Corporation Social Responsibility on the Reform of Corporate Governance}

The word stake first appeared in the 1708 Oxford dictionary, which is explained as stake that people use in the activities. Then, the word "stakeholder" specifically refers to stakeholders. Definition of stakeholders in early stages is that "stakeholders are organizations which could not survive without their support". In 1984, Freeman redefined "stakeholders" from the angle of corporation strategy management that "stakeholders are those benefited or damaged because corporate events and their rights are respected or infringed by corporate activities". 3 The idea laid the outline for later study of stakeholders.

Thus, stakeholder theory and corporation social responsibility spirit are interlinked. Both research categories are similar, including shareholders, employees, suppliers, consumers and communities. The appearance of stakeholder theory undoubtedly has important theoretical value. It laid the theoretical basis for ways and means for late stakeholders involvement in corporate governance research. There is no doubt that the concept of corporation social responsibility goes from stakeholder theory into the research category of corporate governance.

Traditional corporate governance's starting point and foothold are only dedicated to the fulfillment of the interests of shareholders, which is the profit for shareholders and company. The external legal regulation means, such as environmental protection law, consumer law and labor law are to protect the other stakeholders. But social selective ignorance of the negative effect on the company for a long time causes a series of negative effects of "external machine" to the society. Profit is not god, nor the devil. "We should build a harmonious state, and make each of us support profit principle in our own responsibility framework". 4 In fact, the protection of other stakeholders shall be reflected in the purpose of corporate governance, and not simply rely on external regulation means. Therefore, a new governance model should be established to seek maximized shareholder interests and stakeholder interests protection, that is multiple governance mode. Multiple governance essence is to establish company's capital investors' systematic institutional arrangements for their interrelation and inter-influence.

\section{Corporate Governance Models with the Concept of Social Responsibility}

Under the push of world economic globalization and integration, world's corporation governance models present interinfluence and inter-studying. Economic globalization is a kind of economic phenomenon based on market economy. Since the 1980s and 1990s, gradually a unified global market economy is built up. Global corporate governance models presented two forms, respectively Anglo-American corporate governance and German-Japanese corporate governance. These two governance models respectively represent the two purposes of corporate governance, namely "shareholder first", and "stakeholders".

(a) Shareholders-oriented mode ---- Anglo-American corporate governance model

Shareholders-oriented mode is generally pursued in Anglo-American countries, emphasizing the protection for the interests of shareholders, and the supervision of managers is the key point of corporate governance. But do not deny the interests of stakeholders. This model is based on "trust" relationship between shareholders, directors, and managers. As a neutral, director coordinates the interests of all parties. Director of shareholder has fiduciary duty, and has the responsibility of client and shareholders interests service. In addition to this, other stakeholders' protection is realized by reducing the directors' duty of seeking the interests of shareholders. Stakeholders Legislation in the United States is this model. The earliest stakeholders law legislation is in Pennsylvania in the United States. After Pennsylvania, forty states have formulated stakeholders law.

In 2006, British "Company Law" carried on a further modification. In its 170-177, the firm purpose understanding is expanded. Among them, article 172 redefined the general obligation of director as "for the sake of the overall rights and interests of the members of the company and promote company success" as much as possible. It is obvious that the director duty involves a wider scope than before. Under the guidance of the concept, corporate governance is not only concerned 
with the original purpose of company profits, and at the same time involves respect and protection of other relevant interests into the director duty system, and makes the implementation of corporation social responsibility has material foundation and institutional guarantee.

Anglo-American model of corporate law can protect the interests of stakeholders by giving the director larger free space discretions, in addition to a strong trust theory as the foundation. There is another important reason, there are external effective market mechanism in Anglo-American mode. This mechanism includes corporate control market, product market, finance market and manager market. These external restriction mechanisms to a large extent reduce the company's control agency cost pressure on internal governance mechanism.

(b) Stakeholders-oriented mode ---- German-Japanese corporate governance model

German-Japanese mode is known as stakeholder orientation mode. The system design pays attention to the protection of labor rights, of which German co-determination is the model. In 1951, for the first time Germany stipulated employees' participation in corporate governance system in "coal and steel industrial worker equal participation in the decision of the law". In 1952-1976, German legislation established that employee has the right to elect half of the members of the board of supervisors. This "co-determination" has carried on a quite thorough exploration for employees to participate in corporate governance. In Germany, "co-determination" fuses social democracy well together.

In June 2006, “Germany corporate governance code” in Germany settled after modification. While on the basis of "code" maintaining the original dual governance structure, it improves the efficiency of company operations. Focusing on corporate governance modes in coordination with the work of the board of directors and the board of supervisors, it pays attention to the regulation of information disclosure of listed companies, and strengthens the independence of the board of supervisors and directors remuneration disclosure. It shows that German corporate governance is guided by shareholders-oriented corporate governance model, and draws lessons from the essence of Anglo-American corporate governance system. But even so, German corporate governance reform is always carried out within the framework of the original, effectively absorbs correlative excellent system. The purpose lies in effective protection of the existing system.

The characteristics of Japanese corporate governance are embodied in legal person stock holding and the main bank system. Main bank system asks main bank as the company's biggest creditor and the largest shareholders participation in company management, which changes the traditional corporate governance structure. Main bank plays a vital role for benign development of Japanese corporate governance .

\section{The Choice of China in the Reform of Corporate Governance}

While other countries were reflecting and reconstructing the concept of corporation social responsibility all over the world, our country's "company law" listed "corporation social responsibility" as the general terms and conditions, which has the initiative to develop. "Company law" article 5 specified that company engaged in business activities shall bear social responsibility. From corporate governance's social background and corporate governance system analysis, our country's governance structure is more close to Germany's.

Compare and analyze outside companies legislation and practice situation, corporate governance in China can learn the essence of other beneficial system on the basis of the existing company law system framework and to change and respond from the following three aspects. Redefine the company objective and perfect the director duty rules, establish a social responsibility committee under the board, and further improve the worker and creditors participation in corporate governance law.

(a) Expand its purpose explanation rules and perfect the directors obligation

The existing "company law" regulates that company's directors main body such as director of executive owes a duty of loyalty and diligence for the interests of the company. Just starting from the understanding of law, company law seems to be only accepted the directors obligation to the company, without mention the confirmation and protection of other stakeholders. But the problem is 
how to define "company"? If the "company" is taken as a framework interests but not just the company itself, so, this framework includes shareholders, employees and other interests. Director, therefore, owes a duty of care to the main body, and the duty of care is not only for commercial judgment or profit targets, and in social judgment to achieve the balance between shareholders and other stakeholders interests.

At the same time the director duty expanding the scope of main beneficiaries, it should also be noted that the maximization of shareholders is sometimes inconsistent with other stakeholders interests protection. The protection and pursue of shareholders' interests should aim "long-term interests", not for short-term returns of the shareholders' interests. Company should focus on establishing a positive relationship of mutual trust between the main bodies, which contains workers, consumers, creditors, suppliers, etc.5

To respond the problem of corporate governance in China, it is suggested that on the basis of the existing "company law" article 5, further introduce the concept of "other stakeholders" into corporate governance. Increase in 47: "the board of directors has the obligation of the social influence and consequence in performing the functions and powers on its management decisions". At the same time, add in director general obligation article 148: "directors, supervisors and senior managers shall take into account the interests of other stakeholders on the basis of the company's articles in the conduct of his functions and powers to maintain the company's long-term interests".

(2) Set up social responsibility committee in the board

In practice, audit committee, remuneration committee and nomination committee are the three permanent bodies in large co., LTD., the board of directors. Each has emphasize particularly, and the three committees form the joint effort to solve agent problem in business practices. But the business practices' "social impact" assessment and management are still in the stage of fatigue. Therefore, with the board of directors of the tripartite confrontation situation, the author suggests a committee of social responsibility to make social impact assessment and constraints for major business decisions of board of directors, and become a kind of viable path for internal governance fulfilling corporate social responsibility. Generally speaking, in the process of day-to-day operations affecting environmental and social industry and large enterprises, usually adopt this kind of form. For example, British Petroleum, international paper, Alcoa adopt this way in dealing with corporation social responsibility related matters.

The advantages of setting up social responsibility committee for professional evaluation of business decisions so as to promote company's undertaking corresponding social responsibility lie in: first, it can accurately forecast social influence and consequence produced by business decisions and dispose consequences in advance, and form a practical and professional way of evaluation. Second, it can provide the basis for the director of business decisions' social responsibility in the future.

But in the concrete implementation process, about the appointment of a committee member, member's independence and impartiality analysis report are to be further discussed.

(3) Improve the existing corporate governance structure, and strengthen the protection of the interests to the worker.

In theory, the existing corporate governance in our country has formed a kind of control and residual claims by the stakeholders and share company stakeholders-oriented corporate governance mechanism. Although transplantation and localization development of the product of Anglo-American model of corporate governance-the independent director system had been made in our country's "company law", because of the doublication of

its function and the function of the board of supervisors, and lack of effective complementary with other company law system, the independent director system has not really play its effectiveness.

Therefore, allow and strengthen staff's entering the company internal governance, and share decision-making with shareholders become one of the most reasonable and feasible effective paths of the present company. In 2006, our country "company law" revised, made clear rules for workers entering the board of directors, and board of supervisors, but there are still further perfect space. We suggest that "company law" specifically prescribe that the staff in the company achieve a specific percentage, mandatorily implement worker director, and supervisor system; Refine worker director 
and worker supervisor responsibilities and its authority. For example, a board bill should come into force only when adopted by a proportion of worker directors. At the same time, give the director and shareholder director workers equal status in decision-making and accessing to information, etc.

\section{References}

[1]Lu Daifu. Economics and law analysis of corporate social responsibility[J]. Law Press, 2002:96.

[2]Liu Lianyu. Corporate governance and corporate social responsibility[J]. China University of Political Science and Law Press, 2001:66.

[3]Zhao Ling. Corporate governance: theory and system[J]. Law Press, 2009: 80.

[4]Jonathan Charkham. The evergreen company: comparison of Anglo-French-Japan's corporate governance[M]. University of China Press, 2006:398.

[5]Gavin kelly. Stakeholders Capitalism[M]. OuYangying, Chongqing Publishing House, 2001:180 